\title{
Reputation and identity conflict in management consulting
}

\section{William S. Harvey, University of Exeter Business School}

Timothy Morris, Saïd Business School, University of Oxford

Milena Müller Santos, Saïd Business School, University of Oxford

\begin{abstract}
Based on a case study of a large consulting firm, this paper makes two contributions to the literature on reputation and identity by examining how an organization responds when its identity is substantially misaligned with the experience and perceptions of external stakeholders that form the basis of reputational judgments. First, rather than triggering some form of identity adaptation, it outlines how other forms of identity can come into play to remediate this gap, buffering the organization's identity from change. This shift to other individual identities is facilitated by a low organizational identity context even when the identity of the firm is coherent and strong. The second contribution concerns the conceptualization of consulting and other professional service firms. We explain how reputation and identity interact in the context of the distinctive organizational features of these firms. Notably, their loosely coupled structure and the central importance of expert knowledge claims enable individual consultants both to reinforce and supplement corporate reputation via individual identity work.
\end{abstract}

\section{Keywords}

Case study, Identity, Management, Organizational theory, Reputation 


\section{Introduction}

Reputation is a social evaluation based on perceptions of stakeholders about an organization in which past behavior ascribed to an organization is used as a guide to current and expected future standards or actions (Jensen and Roy, 2008; Podolny, 2005; Deephouse and Carter, 2005). It essentially focuses on what is 'different' about an organization compared with others in its set (Lok, 2010). A firm's reputation is an intangible resource that is linked to the organization's perceived ability to create value (Deephouse and Suchman, 2008; Pfarrer et al., 2010) or deliver valued outcomes (Rindova et al., 2010).

Much of the research on corporate reputation has focused on the benefits or consequences of reputation for firm performance (Barnett et al., 2006; Fombrun, 2012; Deephouse, 2000; Rindova et al., 2010; Walker, 2010). However, we know less about how organizations and their members seek to build or maintain reputations. To build reputation, Petkova (2012) argues that firms need consistent, positive evaluations that stakeholders can use to assess underlying quality. Studies of this process have pointed to the importance of consistent behaviors, policies and practices that engender predictability (Dierickx and Cool, 1989; Rindova and Martins, 2012) and the accumulation over time of appropriate expertise and organizational capabilities (Dutton et al., 1994).

Reputation building actions are also linked to the organization's identity. Foreman et al. (2012: 180) propose that 'identity can be seen as the progenitor of reputation...reputation is an external manifestation of identity - that is, a reflection of 'who' the organization is'. Further, Fombrun (2012) argues that companies with strong identities are more likely to gain attention and appreciation. However, identity and reputation are distinct concepts and the external perceptions and judgments of an organization that form the basis of reputation may differ from the internal beliefs of members of the focal organization about 'who or what we 
are' (Fombrun, 2001; Rindova et al., 2005). How, therefore, do organizations respond when identity claims are inconsistent with reputation?

To examine this question we focus on a large consulting firm. Consulting is a particularly appropriate context for several reasons. First, building and sustaining a strong reputation are critical for consulting and other professional service firms to compete successfully (Glückler and Armbrüster, 2003; von Nordenflycht, 2010). Second, identity is a means of expressing the right sort of external image and it also offers a means of dealing with the inherent ambiguity of the service consultants offer and a source of support and self-confidence (Alvesson and Robertson, 2006). Third, the control of client relationships by individual partners means that identity is often fragmented and fluid. Therefore, constructing a unified identity that can be the basis of reputation is likely to be challenging (Alvesson et al., 2015; Whittle, 2006).

This paper's first contribution is to explicate the conflicts that exist between identity and reputation, explaining how and how far they are managed. Existing research shows that external phenomena that challenge or threaten an organization's identity trigger responses ranging from impression management, selective re-categorizing of identity dimensions (Elsbach and Kramer, 1996) to attempts to alter identity (Gioia et al, 2000; Ravasi and Schultz, 2006). In this study, we show that when identity claims are inconsistent with reputational judgments of important external stakeholders, other forms of identity come into play to remediate this gap and act as a buffer for the organization's identity. This finding has implications for understanding how the context of an organization's identity and the relationship between individual and organizational identity influences the capacity to buffer such dissonances (Alvesson and Empson, 2008). We identify three forms of organizational identity work (Kreiner et al., 2015) that facilitate this: shifting levels of attention; enacting a 
different type of identity through 'thought leadership' activity; and relying on external sources of identity to provide additional evidence of value.

A second contribution of the paper relates to the conceptualization of consulting and other professional service firms. As noted above, much work has focused on the importance of reputation and on different forms of identity work within them; we show how reputation and identity interact in the context of the distinctive organizational features of these firms. Specifically, the loosely coupled structure typical of the professional service firm and the knowledge based nature of the service require and enable individual consultants to play a dual role in reinforcing corporate reputational claims and using individual identity work to supplement corporate reputational shortcomings. In reviewing the scope conditions of this case we also explore why identity and reputation dissonance may trigger such remediation responses in some cases but not in others, given that to some extent an organization's identity will always differ from its reputation.

\section{Theory: Corporate reputation and identity}

Reputation is based on evaluations of outsiders relative to other organizations and is derived from direct experience from third party judgments and endorsements (Rindova et al., 2007). It is 'broadly defined as stakeholder perceptions with regard to an organization's ability to deliver valued outcomes' (Rindova et al., 2010: 610) that make it distinctive from others in its peer group. As a distinctive attribute of an organization, a positive reputation is a valuable, intangible asset potentially offering non-trivial forms of competitive advantage (Boyd et al., 2010). Organizations build strong reputations over time by demonstrating consistent behaviors and interactions with stakeholders in delivering, or being able to deliver, valued outputs (Dierickx and Cool, 1989; Lange et al., 2011; Pollock et al., 2015).

Consistency is supported by the organization signaling that it is directing its efforts towards 
meeting the expectations of stakeholders, for example, in terms of product quality, financial performance or as an employer and offers assurance to customers of both reputation and status, particularly where product or service quality is hard to judge ex ante as, for example, in the context of professional service firms (Armbrüster 2004; Sturdy, 2011; Pollock et al., 2015).

A longstanding view of organizational identity is that it reflects central and enduring characteristics that make the organization distinctive (CED) (Albert and Whetten, 1985) and suggests that members of organizations have a collective, shared understanding of its distinctive values and characteristics (Hatch and Schultz, 2002). It implies a degree of difference from other organizations to which the focal firm wishes to be compared but also enough similarity that the firm can be readily accepted as part of that set (Deephouse, 1999). Identity develops over time, reflecting an organization's founding and history and is expressed by its members to stakeholders in terms of values, purpose and knowledge (Gioia et al., 2013) as well as everyday behaviors and practices (Nag et al., 2007).

Foreman et al. (2012: 180) propose that reputation is derived from organizational identity because 'an organization generally acts in ways that are consistent with its "self-view". In other words, identity will help to inform an organization's members' views of their reputation and, through the values and behaviors they display as a result of the organization's identity, will affect how external parties form reputational judgments. However, the notion that reputation is the external expression of an organization's identity is theoretically problematic. Reputation cannot simply be an external reflection of identity because stakeholders draw on a range of cues, selectively using information from multiple sources. As a result, external interpretations of identity will be 'partly warped' (Fombrun, 2012: 97); there will always be some gap between an organization's members perceptions of 'who we are' and its reputation. 
More recent scholarship that questions some of the core assumptions of the CED model of organizational identity also has implications for the links to reputation proposed above. For one thing, identity may be less stable than is implied by the CED properties (Gioia et al., 2013). Further, the notion of a single organizational identity to which all members adhere is contestable, not least because there may be multiple and sometimes conflicting internal views of what that identity is (Glynn 2000; Whittle, 2005; 2006; Gill, 2015; Sveningsson and Alvesson 2003). Having said this, Foreman and Whetten (2002) find that even within multiple identity organizations, identity congruence can occur, which has a significant effect on member commitment. Organizations may idealize or project a particular identity to make themselves attractive, for instance in the labour market and projecting identity may be a means by which organizations pursue reputational aspirations, but this identity may well be inconsistent with or reflect only part of the way an organization's members perceive identity (Kreiner et al., 2006). Indeed, individuals' personal identities may, or may not, be strongly defined by their organization's identity (Alvesson and Empson, 2008).

Similarly, organizations may possess more than a single reputation. Organizations, or parts of them, will be perceived in different ways by different stakeholders and the salience of particular qualities will vary between them (Lange et al., 2011). Existing or potential employees are likely to be more concerned about the firm's reputation as an employer while customers will be concerned about its ability to deliver goods or services of appropriate quality (Barnett and Pollock, 2012). In some organizations, notably professional services and other knowledge based firms, the reputation of a practice area or partner will be salient for clients (Greenwood et al. 2005; von Nordenflycht, 2010). Thus, identity and reputation may interact at different levels or across several dimensions. Management consulting, like other professional service firms, represents an extreme case where many of the tensions between identity and reputation come together. These firms 
produce complex and intangible outputs of professional service firms that make judging quality ex ante or ex post difficult (Armbrüster, 2004; Clark, 1993; Mills et al., 1984; Morris and Empson, 1998). Consequently, reputation is an important means to reduce client uncertainty and vulnerability about the quality of work they are purchasing (Coffee, 2006; Greenwood et al., 2005; Sherer and Lee, 2002; Starbuck, 1992; Sturdy et al., 2013). Reputation is particularly important in management consulting because this sector has characteristics that make quality difficult to judge even relative to other professional services. These include a more ambiguous set of knowledge claims (Clark and Salaman, 1998) and an absence of formal professional qualifications that might act as a signal of quality control or barrier to entry (Faust, 2002). Critical models of the client-consultant interaction highlight the importance of impression management, negotiation of meaningful outcomes and other forms of persuasion by consultants because of the ambiguous nature of their services (Alvesson, 1993; Kärreman and Alvesson, 2009; Fincham and Clark, 2002; Nikolova and Devinney, 2009). Building and projecting an appropriate identity is also important as a means of signaling distinctiveness to parties with which they seek to interact (Sveningsson and Alvesson, 2003; Greenwood et al., 2010).

Identity is also a form of social support that helps counteract the ambiguity of the service being offered: in a world where consultants are often subject to skepticism about the value that they add or the expertise claims that they make, identity is an important source of selfesteem and stability. As Alvesson (2012: 318) puts it, organizational identity counteracts the problematic consequences of operating in a context where consultants 'need to adapt to a variety of groups, subordinate oneself to powerful individuals... and face skepticism in an ambiguous and varied social world'. It can foster cohesion in a relatively fragmented structure in which teams operate semi-autonomously. On the other hand, the loose-coupling characteristic of many consulting and other professional service firms creates the potential for 
a context of lower organizational identity, where identity context is 'a shared sense of belonging to a common social category or an agreement of a 'positive' set of characteristics functioning as a source of identification' (Alvesson and Empson, 2008: 14). Members of professional service firms may believe they work in an organization but not for it and that the organization exists primarily to serve them or as a means for them to enact their expertise. The organization is not then a resource for building a strong collective identity. Indeed, consulting firms' teams can develop the skills to display identity 'front stage' in ways that differ from 'back stage' interactions (e.g. Whittle, 2006). Together, these distinctive characteristics of consulting firms make both identity and reputation important for organizational success and an appropriate site to study how strains between them are managed.

Identity plays an important role in reputation building because firms and their employees act in ways that are consistent with their self-view but we ask what happens if and when reputation differs from identity in ways that challenge or threaten it? Although some degree of identity and reputation dissonance must occur in most organizations, the existing literature shows that organizations and their members can and do respond to significant identity threats both through efforts to manipulate external perceptions and by internal adaptations involving organizational members re-evaluating aspects of their organizational identity (Dutton and Dukerich 1991). For example, Ravasi and Schultz's study of Bang \& Olufsen showed how organizational culture was central to the process of understanding the evolution of identity as well as the creation of new 'identity understandings' (Ravasi and Schultz 2006: 436) through which members made 'new sense of what their organization is really about' (2006: 455). Research also shows that leaders actively seek to alter or reconstruct identity in the face of environmental changes (Gioia et al., 2000; Corley and Gioia 2004). Elsbach and Kramer's (1996) study of business school responses to negative ranking results showed how they 
respond by 'cognitive tactics' (1996: 443) to maintain internal and external perceptions, notably by selectively focusing on particular dimensions of identity not in the rankings and by selectively comparing with other high-ranked organizations. Other studies theorize further the likelihood and nature of responses. For instance, Mitchell et al. (1997) argue that stakeholders' centrality to the focal organization will determine responsiveness. When stakeholders are powerful, legitimate and make urgent claims or are highly 'salient' to the focal organization (Randel et al., 2009), organizations are most likely to respond to identity threats. Similarly, the impression management literature suggests that the characteristics of stakeholders (e.g. their status and familiarity with the firm) will affect their interpretation of events as well as their responses (Gardner and Martinko, 1988; Ginzel et al., 1993).

Responses will also be determined by the extent to which these actors question characteristics that are core to the identity of the firm (Dutton et al., 1994; Gioia et al., 2000). It is more likely organizations can ignore or deflect identity challenges that do not threaten their core identity, whereas challenges that do threaten will more likely prompt defensive or more proactive responses. Further, the nature of identity in the focal organization affects how it can respond. Organizations can have a few or many identities (Albert and Whetten, 1985; Gioia et al., 2000; Randel et al., 2009); multiple identities provide organizations with increased adaptability and flexibility permitting a wider range of responses compared to organizations with a single identity (Pratt and Foreman, 2000).

These accounts suggest organizational identity is susceptible to change when it conflicts with reputational judgments. The reputation literature offers fewer insights into responses. When examining how organizations respond to reputation threat, it has primarily focused on responses to reputational crises (e.g. Rhee and Valdez, 2009). This work shows most responses focus on impression management techniques, including PR, advertising, executive changes and re-branding activities (Carter and Dukerich, 1998; Rindova and Fombrun, 1999), 
or what Rhee and Kim (2012) refer to as 'superficial responses'. More 'substantive'

responses are rare and include re-organizations that centralize control, or asset sales. Further, those authors note that scholars have neglected how organizations respond to less dramatic 'issues' (including poor performance) relative to studies of crises and call for more research in the former area. We respond to these calls by exploring how organizations respond when identity claims are inconsistent with reputational judgments made by influential stakeholders.

\section{Method}

We undertook exploratory research to build and refine theory based on an in-depth case study of a large global management consulting firm and its clients (Eisenhardt, 1989). We selected this as a research site for exploring the relationship between identity and reputation in the context of a broader research agenda around how organizations manage reputation. The organization (forthwith termed Augur Insights) has a single, broad line of consulting services that it groups around the description of strategy consulting. It began as a consulting firm with a strong focus on marketing in Europe and in recent years, has expanded globally. Augur Insights positions itself as an independent European strategy consulting firm with international operations in over 50 offices. There have been several changes to the senior management team as the founder and former CEO has stepped away from the day-to-day operations of the company. The firm is wholly owned by its partners, managed by a small executive team, and is consistently ranked by external validators such as Kennedy Consulting Research \& Advisory as a top ten global management consulting firm.

\section{Data Collection}

We adopted a multi-method approach to data collection, drawing upon interviews, focus groups, non-participant observation and archive materials to which we were given wide access. First, to get a sense of how the firm's reputation (and that of its practices) was 
perceived, we reviewed internal documents, such as discussions of its brand strengths and weaknesses and information from client surveys and other forms of feedback. These took various forms including papers and PowerPoint based documents. We were also provided with access to internal surveys that asked employees about their perceptions of the company's reputation in terms of creativity, prestige, impact, international presence, functional competencies and price competitiveness. We had access to (confidential) corporate documents including benchmarking data and internal rankings of partners on several measures including bid-to-win ratios in client tenders that were seen as proxies for individual reputation. The firm and its practices measured reputation in the following ways: first, in terms of client list with many prominent European multinationals as well as midsized firms who competed globally; second, its bid-to-win ratio, thought to be as good as any of its competitors and, third, according to its own assessments - similar billing rates to other leading firms, all strong indicators of reputational strength (Rindova et al., 2005). We also reviewed press and media coverage of Augur Insights and internal documents that gave us an understanding of the historical development of the firm. We used Factiva to get an overview of the international news coverage of Augur Insights over the past decade. To enhance our understanding of context and reputation, we held preliminary discussions with a small group of clients about Augur Insights' claimed reputation and perceptions of its reputation. We then interviewed clients and consultants about the perceived quality of the firm's work and its reputation, particularly to understand how these affected reputation construction. We wanted to build on the information generated by our document search which gave us a broad view of how Augur Insights' reputation had developed over time, both by acquiring more depth of understanding and detail and by obtaining data on what consultants and clients saw as the reputation building processes. 
We undertook semi-structured interviews $(n=76)$, lasting from 25-70 minutes. The interviews were conducted with employees $(n=36)$ across a range of career levels but primarily we sought the views of senior members of the firm such as partners and directors due to their experience and their roles in developing client relationships and the wider reputation of the firm. We also conducted interviews with clients $(n=19)$, non-clients $(n=4)$, competitors $(n=4)$, alumni $(n=3)$ and potential job candidates $(n=10)$. Repeat interviews and more informal discussions took place on six further occasions with a partner and a senior consultant, who had responsibility inside the firm for its brand and reputation management. The partner was a member of the Executive Committee of the firm and gave us insight into the way that the firm's leadership sought to frame and manage its reputation. While interviewing, we referred to corporate documents as additional sources of information to understand the context, to cross-check interview responses as well as to gain additional perspectives.

Most interviews were conducted face-to-face in the practices' offices over several days, facilitating non-participant observation and more informal discussions. Several were conducted over the telephone when participants were working remotely. Interview questions explored perceptions of the firm's identity and reputation locally and globally and how the firm and/or partners sought to build or strengthen reputation. For instance, we asked how, in their experience, quality of work affected reputation and was affected by it. We also asked what consultants and clients felt made working for Augur Insights distinctive from other consulting firms. We explored how members' perceptions of organizational identity evolved over time. Because at least one author was present in the company's office from the early hours of the morning until late into the evening, informal discussions with individuals and teams over coffee and meals augmented the interviews and were recorded with other observations in a fieldwork diary. 
We obtained a list of clients and non-clients of the firm from Augur Insights and requested interviews. Our purpose here was to build an understanding of the context in which consultants constructed reputation via interaction with clients and other parties as well as to obtain external views of the reputation of Augur Insights' practices. We sought out senior executives who had engaged the firm and could make informed judgments about the firm's reputation and who were generally knowledgeable about the consulting industry. For instance, one informant estimated that during his career he had been involved in over thirty engagements with consulting firms including six with Augur Insights. We asked them openended questions about how they perceived reputation generally and specifically the reputation of Augur Insights compared to its competitors and how this affected their choice of consulting firm and influenced their relationship with it. One author was present at all of the interviews and focus groups in order to maintain consistency in the structure of the questions and discussion. Other authors attended a selection of interviews and participated in the other forms of data collection such as focus groups.

After the interviews had finished, discussions and reviews of findings also took place with partners. Two focus groups were conducted with key informants including senior employees and former employees who were now working for client firms to validate our findings. We also held three one-day meetings in 2011, 2012 and 2013 with a total of 24 partners from different practice areas in which a review of the findings and implications for the firm and its practices' reputations took place. This enabled us to triangulate our findings from the interviews (see also Elsbach and Kramer, 2003: 289). It also allowed further informal discussions with and observations of partners around the organization's identity. 


\section{Data analysis}

All recorded and non-recorded interviews were transcribed, uploaded and coded on the qualitative data analysis software, QSR NVivo9. We adopted a case study analysis approach, which was driven by our prior theoretical propositions and subsequently led to developing a rich case study description (Yin, 2009). A profile was created for each interview, which contained demographic information about the interviewee. Each case profile was arranged according to the structure of the interview schedule to allow for easier data retrieval. The first stage of data analysis involved data exploration during which we moved between the data and the existing literature on identity and reputation. We created a list of first order codes by initially reading through the fieldwork diary, transcripts and protocols and identifying key themes from the interviews and our documentary data sources. Simple descriptive terms were used to name the codes and one researcher coded according to this scheme. During the coding process we developed a common understanding of the data and discussed relationships between the first order codes and the literature. All transcripts were re-read by a third party expert on reputation to double-check the establishment of our propositions and codes as well as to identify if any critical questions or themes had been missed. Preliminary findings were shared with key respondents in follow-up interviews, providing an opportunity for them to respond to the findings and for us to explore additional themes (Lincoln and Guba, 1985).

In the second stage of data analysis we re-examined the data and our first order codes and synthesised these into second order codes and three key categories for this paper (identity claims; reputation conflict; remediation). This stage of the data coding drew on the prior NVivo coding and involved re-reading the interview transcripts. Each of the authors took part in this coding process and researchers engaged in regular discussions to resolve any discrepancies in interpretation. We also regularly checked the fit of the emergent framework 
with the interview data (e.g. Becker, 1970; Glaser and Strauss, 1967; Locke, 2001). Client perceptions of the firm's reputation were not always consistent with the firm's identity claims. We noted the basis of these inconsistencies and how they could be grouped. For the focal firm this meant bridging the gap between its identity claims and perceptions of its reputation in ways we discuss below in more detail (see also Figure 1).

\section{Findings}

\section{INSERT FIGURE 1 ABOUT HERE}

\section{Identity claims}

Asked how they saw themselves and their firm, interviewees referred to what they saw as unique about the firm and its component practices that underpinned its reputation building. Interviewees used the terms identity, culture, brand and image interchangeably to describe the firm in terms of what it did, what it was like to work for, how it had developed and how the firm and its partners were distinctive. We grouped these data around the term 'identity claims' because essentially they were articulating who they were and how they saw themselves (Albert and Whetten, 1985; Chun, 2005). Identity framed for the consultants why they were motivated and how the uniqueness of the firm contributed to the ability to produce work of a particular quality.

Identity claims from Augur Insights and its partners were projected strongly through internal and external marketing messages, for instance in the form of large posters, flat-screen television messages, company stationary and its website where there was a strong unambiguous emphasis on the firm's entrepreneurial, European and pragmatic identity. They were also expressed by some interviewees (particularly senior members) who also stressed 
the firm's elite status, although several others - clients, non-clients and consultants disagreed. As one senior executive of a large corporation put it:

I think my perception would be that [Augur Insights] would almost be a firm that sits somewhere between tier one or tier two. (Non-client)

And a consultant also challenged the status claims:

[In some markets], it doesn't even come onto the same page as the big consultancies [...] it just doesn't have the brand. (Consultant)

Our data show that there were three principal ways that the firm sought to project its distinctive identity claims. First, through demonstrating an entrepreneurial identity; second, through projecting a European identity; third, through providing a pragmatic identity.

\section{Entrepreneurial identity}

Consultants used the term entrepreneurialism in their branding and work engagements to describe what made the firm distinctive internally and to clients. The emphasis on entrepreneurialism derived from the firm's origins and founder and had been formally enshrined as a corporate value and 'part of the company's DNA'. Entrepreneurialism implied openness to market opportunities, new ideas and adaptability to client needs:

I do believe it [entrepreneurialism] corresponds to something that [Augur Insights] people believe in and entrepreneurship is trying to permanently grow on new topics, new markets, take some risks at clients, take some risks internally, by for instance 
pushing more the younger consultants to take responsibility and initiative. So I do believe that the entrepreneurship ...value is differentiating. (Principal)

Several, including the managing partner, used entrepreneurialism to draw a contrast with competitors that were better resourced but less flexible in responding to client demands:

Yeah, we are full of entrepreneurs, we are all entrepreneurs, so it really starts from the consultant level, meaning that all of our consultants, all the way up to the partners, have much more freedom in deciding and in initiating things than in any other consulting firm. (Managing Partner)

\section{European identity}

Reinforcing the distinctive identity of the firm as a whole, consultants (and the firm's internal documentation) referred to its European origins. Consultants habitually drew a comparison with American competitors, whom the consultants felt operated with 'short term' or 'next quarter' models of management and an exclusive focus on shareholder returns rather than a longer term and broader view of building business success. Indeed, the firm had embarked on a project to define how European management models were distinctive and could be enshrined in its practices. Asked what difference this made, one partner said:

From my point of view, we are not [such] streamlined consultants as our American competitors are; solutions are much more customized, much more client-oriented.

Another partner explained that it meant consultants could understand the way that continental European clients worked and their management teams thought. A European identity meant a capacity to customize their services to the European context. For instance, European firms 
had to take into account more explicitly the interests of stakeholders within the organization who had governance rights, such as employee groups. They also had to take into account the longer-term perspective on investments and external parties such as local/state investors. Together, an entrepreneurial and European identity constituted a common narrative for a distinctive identity out of which consultants sought to frame their commitment to quality, defined in terms of adapting strongly to client demands as they occurred on the consulting project and providing advice that was superior to those of its competitors.

\section{Strategy with a difference/pragmatism}

A third dimension of identity related to the knowledge, or distinctive expertise to which the firm laid claim. In particular, claims to pragmatism underpinned the distinctive technical competence of the consultants. The firm and its consultants identified themselves as working in strategy consulting but in a distinctive way that reflected Augur Insights' pragmatic knowhow. This distinctiveness was said to derive from the founder's emphasis on what sort of consulting 'worked' and linked to the entrepreneurial theme:

Entrepreneurialism means we are pragmatic: we do what the client needs us to do rather than saying that is not our business. (Partner)

Pragmatism was said to be reinforced by the sectoral structure of the firm and internal development policies. Consultants were allocated to a sector early in their careers so that they developed deep but specific expertise, for example in retailing or aerospace: 
The difference is we train consultants straightaway in sectors so they have deep knowledge by two or three years. By the time they are seniors they can be thought leaders. (Partner)

Consultants emphasized the firm's knowledge enabled them to deliver 'practical and implementable solutions'. They took pride in being more 'human' than many of their betterknown competitors: who were described as abstract strategists, good at analysis but not so strong in execution. Thus: 'We pick up where [well-known competitor ] drops off.'

I think [clients are] grateful for it, having a practical consultancy, with solutions that could be...can well be implemented. And they also often tell us that they're happy to get consultants they can really discuss with, like on a human...human level, if you can say so. They tend to find that, at [Augur Insights], we're kind of approachable. (Senior Consultant)

According to Augur Insights' consultants, this meant that they customized solutions better than their competitors:

We have a slogan that's called, or we used to have it, "Strategies that work", "Creative strategies that work" [...] it's not only about developing strategies that are the best strategies, but also strategies that are the best strategies for this client in this situation. (Senior Consultant) 
Of course, this sort of claim is commonplace among consulting firms (see for instance Financial Times, 2013) but, nonetheless, for Augur Insights members it was a distinctive part of their history and identity.

\section{INSERT TABLE 1 ABOUT HERE}

\section{Reputation conflict}

So far we have discussed how Augur Insights' consultants defined their reputation out of their identity claims. Augur Insights has used several vehicles to try and affirm its reputation, including promoting a values system across the organization emphasizing entrepreneurial thinking, delivering excellent work and working closely with the client. However, clients, third parties and some consultants did not accept these claims uncritically. Augur Insights' consultants themselves recognized some of their reputation limitations. Although there was no confusion about the firm's European identity, it was often difficult to pinpoint for outsiders what this identity claim meant. For example, one partner said:

\footnotetext{
We're trying to major on the idea of a European consulting firm but it's not got much traction because it's hard to say what it means in practice or why it might be useful to clients.
}

This was echoed by external parties. For example, one non-client said:

Yes, [Augur Insight] people, you know you're dealing with a European firm somehow, if only because of the name and the languages. That must make some sort 
of difference. It means that, in the context of Europe, you might just get a greater degree of sensitivity from the Europe-based player compared with a parachuted-in American, but that might be slightly unfair. (Non-client)

The identity claims around entrepreneurialism were similarly described as vague by several partners as well as clients.

We talk [about being entrepreneurial] but that can just mean we do anything rather than have a distinctive expertise which we sell to clients.

In general, there was an inconsistency between the identity claims of the firm and its reputation.

Augur Insights' reputational claims as a strategy consultancy, albeit with a pragmatic spin also created problems. This positioning had developed gradually out of a series of landmark projects in the 1990s in which they had been engaged to restructure large state-owned enterprises for privatization. The media coverage these generated brought to prominence the core practice of the firm and had, in the view of clients and competitors as well as consultants in Augur Insights, established a new sort of reputation for the firm (Sueddeutsche Zeitung, 2004; Dow Jones Newswire, 2009; German News Digest, 2009). Generally, these stakeholders described the firm's reputation being for organizational restructuring rather than 'pure strategy' and pragmatic but noted that the firm's emphasis on both pragmatism and strategy actually contributed to a perceived lack of distinctiveness:

It's not a high level. I did not come out saying, wow, I learned something today. The kind of presentation and content was not impressive. We used them for one workshop and seminar - they did not deliver anything exceptional. (Client) 
Other clients also said pragmatism and strategy meant 'everything and nothing' and is 'too easy to assert' and 'every firm would say things like that'. As one partner put it:

I never use that term [pragmatic] in pitching for work because it is meaningless. It implies we'll do anything rather than we have any sort of specialist positioning. I always emphasize focus and expertise.

And one client explained that she found the pragmatism claim contradictory:

I know what they are trying to say. When they work with you they're practical, but actually I find their thought-leadership models and the stuff they write to be very abstract, like a quasi-academic treatise, much more so than other [consulting firms].

\section{Remediation}

The evidence above highlights that the firm's identity claims were not aligned with its reputation. The company had a well maintained website and a substantial set of marketing materials which promoted its distinctive values and expertise claims but clients that we interviewed regarded them as no more than the typical propaganda all firms offered and of no influence on engagement decisions or their judgment of the firms. When we asked Augur Insights consultants if and how they reconciled the gap between their claimed identity and the reputational perceptions of clients and others, they acknowledged the everyday reality of this gap. We were intrigued that they also indicated this was not a major problem either for who or what the firm was or for themselves as consultants with Augur Insights and the way they 
carried out their work. We therefore explored how the 'strain' between internal identity claims (entrepreneurial, European and pragmatic) was bridged, if at all.

The emphasis on engagements by clients and consultants prompted us to focus on them as the key platform where reputation claims came under the microscope and as the locus of actual identity work. We found that there were three different remedial actions that the members of the firm adopted, each of which demanded variations around the claimed organizational identity: first, shifting the level of attention; second, trust building through claims to thought leadership; and third, emphasizing value.

\section{Shifting levels}

We observed that there was a shift in the focus of reputation to the partner level rather than the reputation of Augur Insights itself. Partners would reassure clients of their own credentials (i.e. reputation for particular types of expertise and experience) during the pitch by providing testimonials, outlining their track record with other high status clients and by inviting previous clients (usually retired) to present with the pitch team. As both clients and consultants emphasized, this made sense because in deciding whom to engage, the client was concerned with the quality and integrity of the partner and his or her team, rather than the reputation of the firm as a whole. Partner credentials were presented via a combination of formal interviews and informal discussions in which the client aimed to assess the ability to deliver (competence and experience) combined with compatibility (an affinity with the hiring client). For instance, one retail sector client and a partner whom we interviewed separately and together, outlined how the substance of the engagement discussion concerned the partner's knowledge and experience with various online retailing innovations and the partner's track record in executing an online strategy. In these discussions the combination of deep understanding of online retail strategy innovations and experience with other major 
European retailers in implementing these innovations were the critical selling point. Clients would also seek assurances such as the composition and collective experience of the team and how frequently the partner or partners would be on-site. As one client tersely put it:

This is not rocket science and I'm not hiring the best scientist. I'm hiring for competence. Do I trust the partner and the team to deliver?

Clients and partners described corporate reputation as the 'entry ticket' because hiring was a political process in which the 'rubber stamp' of a reputable company helped to legitimize their procurement choices:

[Clients] will come up with a short-list of consultant companies they are willing to invite and to have a beauty contest, but to get on that short-list, you have to have the kind of reputation to get on the list (Client).

Thus, the gap between identity claims and clients' perceptions did not fatally flaw the selection process in bids for projects. Indeed, the entrepreneurial identity of the firm and partners reinforced this view of corporate reputation as an umbrella assurance. Several consultants actually described themselves as entrepreneurs nested within a wider organization but with minimal call on its resources - working in but not for the organization.

Trust building from thought leadership claims

Second, we found the partner acting as a 'disinterested' broker of useful knowledge about sector or market developments to clients with no explicit 'sell' involved: the partner therefore offered his/her expert information and insight to demonstrate competence or 'thought 
leadership'. Partners did this, for instance, by organizing meetings with clients and nonclients in their sector at which they discussed latest trends and sector-models of innovation or competition. Or they sent communications to clients about recent or up-coming events and news with their own perspective on the general implications for the dynamics of the sector, such as sales, pricing or areas of innovation.

What can work is when we present information to clients about the sector, show them our deep expertise, not as salesmen. (Partner)

The firm tried to support such expertise claims through launching a journal, organizing conferences and developing social media links, all of which aimed to demonstrate their 'thought leadership' and distinctively pragmatic mode of operating. Here they were following the success of other major management consultancies:

[Competitor A] has its journal and that shows their thought leadership. We have something similar but not as well known, so I try to show my clients I'm thinking, too, about the way the markets are going and what it means for them. (Partner)

Brokering knowledge as the sector expert also positioned the partner as having a professional identity (Pratt et al., 2006) in which the client's interests were his or her own regardless of commercial arrangements. They acted with 'altruism' as one client put it even if the longerterm goal was to build commercial commitment. It also reinforced the consultants' sense of being more than 'hired hands', suggesting a stronger professional identity located on their sectoral and functional expertise and acted as a reputational bridge by indicating competence and broad expertise. But offering information or advice could get in the way of the relentless 
pursuit of sales in the short run. Partners said that they felt deeply conflicted between the need to sell and achieve their targets and disinterested behavior that most said they enjoyed and signaled professionalism. These actions were seen as a means by which the partners could build trust with clients and demonstrate a relatively distinctive position compared to their competitors.

\section{Emphasizing value}

The third action to deal with identity and reputational conflict was what we call emphasizing value and this relates back to the firm and its members' claims to be pragmatic and entrepreneurial in their engagement work, as a form of differentiation from other consulting firms. Pragmatism was widely asserted by many consultants we interviewed but was also seen by some to be meaningless. Augur Insights sought to manifest the emphasis on value in two ways. One was that the consulting teams were loaded more heavily with senior consultants including partners so that there was greater experience in the consulting project than might normally be offered by other competing firms. For clients, loading on experience was meant to be insurance that they would obtain high quality, practical results:

I think that clients basically get more, I think they get more focused [i.e. try to reduce] on the cost side of a project, while there's an increasing level of expectation on the quality [i.e. seniority of the consulting team]. (Client)

A second manifestation of over-delivery took the form of additional effort on client projects. As one Senior Manager put it: 'Going the extra mile for clients and making it tailor-made for clients.' And to do this, consultants had to 'put themselves in the mindset of the client...see the world from the client's point of view', but also to build a culture in which consultants 
'thought of the client first, thought like the client.' The intention was to provide extra value via the delivery of non-contracted services to compensate for relative reputational weakness:

The way we work is that very often people over-deliver. I'm not sure whether we have that reputation, but if somebody has worked with us a couple of times then they would recognise they can get more. (Partner)

Over-delivery aimed to demonstrate that the firm was deeply committed to the client's goals although this remedial action was to some extent problematic. Some clients saw positive reputational implications and for consultants it demonstrated a deep commitment to the client's goals which reinforced a sense of identification with them. However, it also undermined some aspects of Augur Insights' identity aspirations of being an elite (strategy) firm, implying the firm would do anything, and was therefore not distinctive.

\section{Discussion}

In this paper we explore how significant identity and reputational differences may be managed. Our starting point is that the proposition that identity is expressed through reputation, that is, 'reputation is an external manifestation of identity' (Foreman et al., 2012: 180) was problematic. We found significant inconsistency between the organization's broad identity and reputation prompting us to ask how it responded. While other studies have found that external pressures from important stakeholders induce members to re-evaluate their organization's identity (e.g. Dutton and Dukerich 1991; Ravasi and Schultz 2006), we found little evidence of such re-evaluation or change in identity. Rather, it appeared that the organization's identity claims were buffered as individuals remediated the disconnect between the identity narrative and the firm's reputation. Members pragmatically worked 
with the broad identity claims, selectively referring to and using them as they saw fit or rejecting them at other times.

Consistent with other studies of identity in consulting (e.g. Alvesson, 2001), they modified or supplemented them where work, or the pitching for work, actually occurred. Whittle (2005) also finds that conflicted identities are an important means of consultants managing contradictory pressures when working with different groups, although in her study consultants did not recognize such conflicts because they spent little time reflecting on this. In this work arena, other identities - of the partner and consultants in work teams - came into the foreground to supplement and sustain rather than replace the projected identity almost like patching devices to resolve temporary breakdowns (Brown and Eisenhardt, 1997). Our findings have some similarity to the way Elsbach and Kramer (1996) found members selectively deployed particular self-affirmation and impression management to address identity threats, but here we emphasize the active role of individuals in deploying different identities and their more agentic sense-giving processes as they inter-acted with external parties. Thus, the dissonance between reputation and identity did not result in changes in the organization's identity, nor did it appear to place substantial strain on members' perceptions of their own identities or those of their teams. Rather, these actions provided what Kreiner et al. (2015) call forms of 'identity elasticity' providing continuity in terms of the core identity features.

Our findings thus build on the concept of organizational intensity and the relationship between organizational and individual identities (Alvesson and Empson, 2008). A straightforward interpretation could conclude a case of a weak organizational identity leaving little imprint on individual members. Yet the organization's identity was clearly defined by the founder's imprint on the way the firm should work [entrepreneurial] and how it was distinctive [notably, its otherness from competitors - for instance, European-ness] and it was 
widely known and accepted by the firm's members. This is likely to be common among start-up, family and eponymous firms with distinct histories around key people. We found that this strong identity co-existed with a somewhat low organizational identity context. In other words, the organizational identity did not intrude on everyday life in terms of being a common social category or source of meaning-making ('who we are'). Again, this is likely to be common among firms where members are very clear around their organizations' values, but where these values have little impact upon the way they conduct their work. We found that the signal was clear from the organization, but the volume was turned down by members. The low identity context derived from the firm's loose coupling, the longstanding emphasis on individuals 'hunting' for their own work and the limited codified knowledge base, that is, what we know and how we enact it via particular methods or processes, was a source of identity formation in this consulting firm (see also Alvesson and Empson, 2008). This meant individuals were only loosely connected to the common organizational narratives in their day-to-day work. Individuals were encouraged and incentivized to act individually and saw themselves as the focus of how one defines oneself in work contexts (Kreiner et al., 2006). Hence, when identity claims differ significantly from reputation, this does not trigger changes or reflection upon organizational identity but is addressed instead by individual identity work.

Three actions bridged the identity/reputation gap, each involving different forms of individual identity work, that is the cognitive, discursive and behavioral processes by which individuals can sustain or adapt an organization's identity (Sveningsson and Alvesson, 2003; Watson, 2008). The first action shifted the level of attention and focus of reputation from the organization to the consultants. This finding contributes to theory building on reputational interactions across organizational levels which, thus far, has focused on the impact of powerful 'celebrity' executives on organizational reputation (Fombrun, 1996; Graffin et al., 
2013; Hayward et al., 2004). However, the interaction of organizational and individual identities remains less well examined (Kreiner et al., 2006; Brown, 2014). Our findings suggest that different levels of reputation can be complementary: they perform different functions and are interpreted in different ways by stakeholders. Thus, corporate reputation plays a quality assurance role (Coffee, 2006) while individual consultants embody more concretely the entrepreneurial identity claims of the firm in building client relationships. Second, and building on the change in levels, the shift from a commercial to a 'disinterested expert' relationship at the individual level involved identity work to broaden the client relationship. Here the consultants enacted a different sort of professional identity but both they and the clients were also aware that there was an underlying commercial rationale, an ambiguity in the 'disinterestedness' such that professionalism was tinged with a 'soft' instrumentalism. Shifts like this into a professional/commercial identity support other work that has found consultants may use expertise claims creatively (e.g. Alvesson and Robertson, 2006) or flex their roles and identities: Pratt et al. (2006) refer to this as identity patching in their study of professional identity construction (see also Whittle, 2006). Here, we show how such role flexing and identity customization can be deployed to build or adjust a reputation. We also emphasize how consultants have to deal with different identity demands driven by conflicting organizational requirements: thus, projecting an altruistic professional identity is valued and encouraged at the same time as incentive and monitoring systems undermine this. Third, emphasizing value (through team composition and extra effort) is not unique to this case and has been found elsewhere as a way to build benevolence among clients (e.g. Sturdy et al., 2013; Nikolova et al., 2014) but we build on that finding to show how it enabled buffering between identity claims and reputation via a process of building strong mutual identity with the client which was reinforced by the consultants actually being embedded within the client organization. This approach is meant to signal the requisite reputational 
qualities of competence and 'can-do' requiring substantial commitment and extra effort by the consulting teams (Pollock et al., 2015). As Alvesson (2010) also found, the organization's culture and strong career incentives reinforced this approach of strong identification with the client.

The above three actions are mutually reinforcing and each has identity implications. Shifting levels opens up the possibility of multi-level reputations operating in complementary ways; it also focuses on the consultant's identity rather than the firm's. The emphasis on disinterested expertise follows and builds reputational depth as a 'trusted advisor' as well as reinforcing the consultant's identity. The emphasis on value means giving extra time-commitment to the client; by being embedded in the client organization consultants also come to identify more with the client, as Alvesson (2012) notes (although we acknowledge this had problematic implications for reputation too). Collectively, these actions constitute the mechanism that buffers the gap between the organization's identity and its reputation by re-focusing attention to the identity of the consultant.

This finding also has implications for our understanding of how reputational shortcomings can be addressed. Research in this area has mainly focused on reputation damage and repair: for instance, Rhee and Valdez (2009) suggest a firm's reputation can be repaired if stakeholders perceive it has the capability and intent by sending positive signals to other stakeholders. Our research stands in contrast to the repair model by finding that solutions to shortcomings in reputational claims are not a straightforward matter of impression management via re-signaling or re-branding but entail a shift in the level of focus and substantial identity work building trust via three remedial actions (see Figure 1). We also outline how trust can be enhanced when firms seek to remediate external skepticism. The process of trust building in consulting is a social process between parties that seek to reduce uncertainty and vulnerability (while recognizing that these can never be eliminated). 
Trust building therefore has to go beyond demonstrating credentials or what Nikolova et al. (2014) call 'good reasons' to trust. Their model has both cognitive and emotional dimensions focusing on alignment of expectations on work processes and outcomes as well as 'likability' or an affective connection. Our work builds on this by showing how displaying a professional identity via 'altruistic professionalism' and demonstrating strong client identity in offering forms of extra value builds cognitive and affective dimensions of trust and enables clients to make 'leaps of faith' (Nikolova et al., 2014).

Finally, we contribute to theories of the professional service firm by showing how organizational and individual identities and reputations interact to sustain each other.

Existing accounts propose that large professional service firms trade on the reputational capital of individual partners (Gilson and Mnookin, 1985) and particular practice groups, often those that were the original or canonical to the firm (Greenwood et al., 2005). Reciprocally, individual partners' reputations are also supported by the reputation of their firm so that there is an interactive effect on reputation-building. Here, we show how professional service firms constitute their corporate reputation claims from beliefs about their distinctive organizational identity, based on narratives about their origins and development. But why do they persist with such reputational claims in the face of client skepticism? One reason may be that they send positive signals to other relevant parties, such as employees or potential hires. Another is that in the context of a sector where other claims to distinctiveness and advantage are simply difficult to demonstrate or sustain, a reputational claim to distinctiveness is strategically the only option (Starbuck, 1992). Of importance here is the nature of the professional service firm as a coalition of expertise based practices headed by partners (Greenwood et al., 1990; Anand et al., 2007; von Nordenflycht, 2010). It is this loosely coupled structure and the knowledge based nature of the service that both demands and enables the dual role of partners to reinforce the corporate reputational claims - even if 
they do not fully believe in them - and to use individual identity work to supplement the corporate reputational shortcomings. We conclude that part of the competence of becoming a partner is to learn how to flex effectively between organizational and individual levels in such identity work.

\section{Limitations and future directions}

There are several limitations to this research that can be addressed in future studies. First, we acknowledge that in our research question there is an assumption organizations do respond to differences between their identity and reputation. While we emphasized above that most, if not all, organizations will have some gap between internal and external perceptions, this prompts the important prior question of when, or under what conditions, do organizations respond (or not) which requires further investigation. It is plausible to argue that one such condition is the degree and nature of such dissonance given identity concerns facets of the organization that are central and distinctive. Small differences are likely to be perceived as insignificant or may not be observed, in which case adjustment is either unlikely or irrelevant. This suggests that the saliency of the difference is the critical variable prompting identity responses but future empirical research should explore at what point and why organizations perceive the dissonance to be sufficiently large to take action.

Second, theory suggests when scarce resources are threatened, perhaps because a valued client or third party threatens to terminate a relationship or the focal organization cannot generate funding or legitimacy, then the focal organization is more likely to act (Suchman, 1995; Pfeffer and Salancik, 2003; Pollock and Rindova, 2003). Future research should explore the possibility of resource-based (and attention-based) drivers of responses. Third, research can explore if and how different organizational forms will affect the likelihood and nature of responses. Thus, our findings suggest loosely couple organizations are likely to 
respond to dissonances in different ways than tightly coupled ones, or have the capacity to adapt at different organizational levels (Weick, 1979). Consulting and other professional service firms typically display features of loose coupling that facilitate local and/or partial responses such as we document here but our findings can be further refined by comparative analysis between firms with different degrees of tightness/looseness, for instance by exploring the proposition that tighter coupled organizations pursue more centrally administered or programmatic adjustments. The low identity context is likely to be facilitated by loose coupling but they are not the same so future research should consider both the degree of loose-coupling and the identity context separately.

Fourth, while certain types of organization, such as consulting firms typically make exaggerated claims around their elite identities (Alvesson et al., 2015), ironically, clients are unlikely to accept these uncritically because many are experienced buyers who have worked as professionals and/or co-produced knowledge in partnership with professionals. This suggests that the nature of stakeholder groups and the degree of overlap between internal and external groups will also affect the likelihood of reacting to identity-reputation misalignment (Christensen and Askegaard, 2001; Christensen et al., 2008).

Fifth, response likelihood and type will plausibly be conditioned by how dissonance is perceived. For instance, dissonance may be perceived not so much as a threat to identity but as an opportunity for identity enhancement or change, as members make sense of their organization in new ways (Corley and Gioia 2004; Ravasi and Schultz 2006). Finally, while we have shown how different forms of identity and reputation can be brought into play to deal with dissonance, it is possible that dissonance may also be resolved by changes that align identity claims more with reputation, as has been shown in studies of identity threat and response: understanding when and how organizations select different sorts of responses to dissonance is therefore an important path for future research. These limitations suggest many 
promising areas for future research that can focus on cognition and behaviors and which would contribute to richer theorization of the relationship between identity and reputation.

\section{Conclusions}

This paper starts by recognizing that the identity claims of firms may be markedly different from their reputation. While such differences may not constitute crises, they are often sufficiently important that they require a response. We make two important contributions to the identity and reputation literature. First, we show how organizations can effectively buffer their identity when threatened by reputational judgments through a set of remedial actions which shift the focus away from the organizational level to individual-level identities with clients. In contrast to studies that have shown how identity shifts in response to external threats or perceptions, we argue that shifting levels of attention, enacting a different type of identity and relying on external sources of identity buffer the identity claims of organizations, even as they continue to conflict with its reputation. Second, we show that this buffering is facilitated by loosely coupled structures in which the identity context is lower, even when the organization's identity is coherent and clear. Such features, typical of knowledge based firms, allow them to respond to tensions between organizational identity and reputation through consultants using individual identity work in the execution of day-to-day client work.

\section{Acknowledgements}

We would like to thank Christopher Wright, Michael Gill and Emma Jeanes for their helpful feedback on earlier drafts of this paper. We also wish to thank Mathew Sheep, Associate Editor of Human Relations, as well as three anonymous reviewers for their valuable insights, feedback and guidance with the direction of this paper. 


\section{Funding}

This study was supported by the Oxford University Centre for Corporate Reputation.

\section{References}

(The) Financial Times (2013) Full reference removed to anonymise company.

(The) Wall Street Journal (1999) Full reference removed to anonymise company.

Albert S and Whetten DA (1985) Organizational identity. Research in Organizational Behavior 7: 263-295.

Alvesson M (1993) Organizations as rhetoric: knowledge-intensive firms and the struggle with ambiguity. Journal of Management Studies 30(6): 997-1015.

Alvesson M (2001) Knowledge work: Ambiguity, image and identity. Human Relations, 54(7): 863-886.

Alvesson M and Robertson M (2006) The best and the brightest: The construction, significance and effects of elite identities in consulting firms. Organization 13(2): 195-224. Alvesson M and Empson L (2008) The construction of organizational identity: Comparative case studies of consulting firms. Scandinavian Journal of Management, 24(1), 1-16. Alvesson M (2010) Self-doubters, strugglers, storytellers, surfers and others: Images of self-identities in organization studies. Human Relations 63(2): 193-217.

Alvesson M (2012) Managing Consultants. Control and Identity. In Kipping M and Clark T (eds) The Oxford Handbook of Management Consulting Oxford: Oxford University Press, 303-324.

Alvesson M, Kärreman D and Sullivan K (2015) Professional service firms and identity. In Empson L, Muzio D, Broschak JP and Hinings B (eds) The Oxford Handbook of Professional Service Firms Oxford: Oxford University Press, 403-424. 
Anand N, Gardner HK and Morris T (2007) Knowledge-based innovation: emergence and embedding of new practice areas in management consulting firms. Academy of Management Journal 50(2): 406-428.

Armbrüster T (2004) Rationality and Its Symbols: Signalling Effects and Subjectification in Management Consulting. Journal of Management Studies 41(8) 1247-1269.

Barnett ML, Jermier JM and Lafferty BA (2006) Corporate reputation: The definitional landscape. Corporate Reputation Review 9(1): 26-38.

Barnett ML and Pollock TG (eds) (2012) The Oxford Handbook of Corporate Reputation. Oxford, Oxford University Press.

Becker H (1970) Sociological Work: Method and Substance. New Brunswick: Transaction. Boyd BK., Bergh DD and Ketchen DJ (2010) Reconsidering the Reputation-Performance Relationship: A Resource-Based View. Journal of Management 36(3): 588-609.

Brown SL and Eisenhardt KM (1997) The art of continuous change: Linking complexity theory and time-paced evolution in relentlessly shifting organizations. Administrative Science Quarterly 42(1): 1-34.

Brown AD (2014) Identities and Identity Work in Organizations. International Journal of Management Reviews [early view].

Carter SM and Dukerich JM (1998) Corporate responses to changes in reputation. Corporate Reputation Review, 1(3): 250-270.

Christensen LT and Askegaard S (2001) Corporate identity and corporate image revisited - A semiotic perspective. European Journal of Marketing, 35(3/4): 292-315.

Christensen LT, Morsing M and Cheney G (2008) Corporate Communications. Convention, Complexity, and Critique. Sage, London.

Chun R (2005) Corporate reputation: Meaning and measurement. International Journal of Management Reviews 7(2): 91-109. 
Clark T (1993) The market provision of management services, information asymmetries and service quality - some market solutions: An empirical example. British Journal of Management 4(4): 235-251.

Clark T and Salaman G (1998) Creating the "right" impression: Towards a dramaturgy of management consultancy. Services Industry Journal 18(1): 18-38.

Coffee JC (2006) Gatekeepers: Professions and Corporate Governance. New York: Oxford University Press.

Corley KG and Gioia DA (2004) Identity ambiguity and change in the wake of a corporate spin-off. Administrative Science Quarterly 49(2): 173-208.

Deephouse DL (1999) To be different, or to be the same? It'sa question (and theory) of strategic balance. Strategic Management Journal 20(2): 147-166.

Deephouse DL (2000) Media reputation as a strategic resource: An integration of mass communication and resource-based theories. Journal of Management 26(6): 1091-1112. Deephouse DL and Carter SM (2005) An Examination of Differences Between Organizational Legitimacy and Organizational Reputation. Journal of Management Studies 42(2): 329-360.

Deephouse DL and Suchman M (2008) Legitimacy in organizational institutionalism. In: Greenwood R, Oliver C, Sahlin K and Suddaby R (eds.) The SAGE Handbook of Organizational Institutionalism. London: SAGE, 49-77.

Dierickx I and Cool K (1989) Asset stock accumulation and sustainability of competitive advantage. Management Science 35(12): 1504-1511.

Dow Jones Newswire (2009) Full reference removed to anonymise company.

Driver M (2015) How trust functions in the context of identity work. Human Relations 68(6): 899-923. 
Dutton JE and Dukerich JM (1991) Keeping an eye on the mirror: Image and identity in organizational adaptation. Academy of Management Journal, 34(3): 517-554.

Dutton JE, Dukerich JM and Harquail CV (1994) Organizational images and member identification. Administrative Science Quarterly 39(2): 239-263.

Eisenhardt KM (1989) Building theories from case study research. Academy of Management Review, 14(4): 532-550.

Elsbach KD and Kramer RM (1996) Members' responses to organizational identity threats: Encountering and countering the Business Week rankings. Administrative Science Quarterly, 41(3): 442-476.

Elsbach KD and Kramer RM (2003) Assessing Creativity in Hollywood Pitch Meetings: Evidence for a Dual-Process Model of Creativity Judgments. Academy of Management Journal 46(3): 283-301.

Faust M (2002) Consultancies as Actors in Knowledge Arenas: Evidence from Germany. In: Kipping M and Engwall L (eds) Management Consulting: Emergence and Dynamics of a Knowledge Industry. Oxford: Oxford University Press.

Fincham R and Clark T (2002) Introduction: The Emergence of Critical Perspectives on Consulting. In: Clark T. and Fincham R. (eds) Critical Consulting. New Perspectives on the Management Advice Industry. Oxford: Blackwell, 1-18.

Fombrun CJ (1996) Reputation: Realizing Value from the Corporate Image. Boston: Harvard Business School Press.

Fombrun CJ (2001) Corporate reputations as economic assets. The Blackwell Handbook of Strategic Management, 289-312.

Fombrun CJ (2012) The building blocks of corporate reputation: definitions, antecedents, consequences. In: Barnett ML and Pollock TG (eds) The Oxford Handbook of Corporate Reputation. Oxford: Oxford University Press, 94-113. 
Foreman PO and Whetten DA (2002) Members' Identification with Multiple-Identity Organizations. Organization Science 13(6): 618-635.

Foreman PO, Whetten DA and Mackey A (2012) An identity-based view of reputation, image, and legitimacy: Clarifications and distinctions among related constructs. In: Barnett, ML and Pollock TG (eds) The Oxford Handbook of Corporate Reputation. Oxford: Oxford University Press, 179-200.

Gardner W and Martinko M (1988) Impression management: An observational study linking audience characteristics with verbal self-presentations. Academy of Management Journal 31(1), 42-66.

German News Digest (2009) Full reference removed to anonymise company.

Gill, MJ (2015) Elite identity and status anxiety: an interpretative phenomenological analysis of management consultants. Organization 22(3): 306-325.

Gilson, RJ and Mnookin RH (1985) Sharing among the human capitalists: An economic inquiry into the corporate law firm and how partners split profits. Stanford Law Review 37: 313-392.

Ginzel LE, Kramer RM and Sutton RI (1993) Organizational impression management as a reciprocal influence process: The neglected role of the organizational audience. Research in Organizational Behavior 15, 227-266.

Gioia DA, Schultz M and Corley KG (2000) Organizational identity, image, and adaptive instability. Academy of Management Review, 25(1): 63-81.

Gioia DA, Patvardhan SD, Hamilton AL and Corley KG (2013) Organizational Identity Formation and Change. Academy of Management Annals 7(1): 123-193.

Glaser B and Strauss A (1967) The discovery of grounded theory: Strategies for Qualitative Research. Chicago: Aldine. 
Glynn MA (2000) When cymbals become symbols: Conflict over organizational identity within a symphony orchestra. Organization Science 11(3): 285-298.

Glückler, J and Armbrüster T (2003) Bridging uncertainty in management consulting: the mechanisms of trust and networked reputation Organization Studies 24(2): 269-297.

Graffin SD, Bundy J, Porac JF, Wade JB and Quinn DP (2013) Falls from Grace and the Hazards of High Status. The 2009 British MP Expense Scandal and Its Impact on Parliamentary Elites. Administrative Science Quarterly 58(3): 313-345.

Greenwood R, Hinings CR and Brown J (1990) P2-form” strategic management: Corporate practices in professional partnerships. Academy of Management Journal 33(4): 725-755.

Greenwood R, Li SX, Prakesh R and Deephouse DL (2005) Reputation, Diversification, and Organizational Explanations of Performance in Professional Service Firms. Organization Science 16(6): 661-673.

Greenwood R, Morris T, Fairclough S and Boussebaa M (2010) The Organizational Design of Transnational Professional Service Firms. Organizational Dynamics 39(2): 173-183. Hatch MJ and Schultz M (2002) The dynamics of organizational identity. Human Relations, 55(8): 989-1018.

Hayward ML, Rindova VP and Pollock TG (2004) Believing one's own press: The causes and consequences of CEO celebrity. Strategic Management Journal 25(7): 637-653. Jensen M and Roy A (2008) Staging exchange partner choices: When do status and reputation matter? Academy of Management Journal 51(3): 495-516.

Kärreman D and Alvesson M (2009) Resisting resistance: Counter-resistance, consent and compliance in a consultancy firm. Human Relations 62(8): 1115-1144.

Kreiner GE, Hollensbe EC and Sheep ML (2006) On the edge of identity: Boundary dynamics at the interface of individual and organizational identities. Human Relations 59(10): 1315-1341. 
Kreiner GE, Hollensbe E, Sheep ML, Smith BR and Kataria N. (2015) Elasticity and the Dialectic Tensions of Organizational Identity: How Can We Hold Together While We Are Pulling Apart? Academy of Management Journal, 58(4): 981-1011.

Lange D, Lee PM and Dai Y (2011) Organizational Reputation: A Review. Journal of Management 37(1): 153-185.

Lincoln Y and Guba E (1985) Naturalistic inquiry. Sage, Beverly Hills, CA. Locke K (2001) Grounded theory in management research. London: Sage.

Lok J (2010) Institutional logics as identity projects. Academy of Management Journal 53(6): $1305-1335$.

Mills PK, Chase RB and Margulies N (1984) Motivating the Client/Employee System as a Service Production Strategy. Journal of Library Administration 5(1): 97-112.

Morris T and Empson L (1998) Organisation and expertise: An exploration of knowledge bases and the management of accounting and consulting firms. Accounting, Organizations and Society 23(5): 609-624.

Mitchell RK, Agle BR and Wood DJ (1997) Toward a theory of stakeholder identification and salience: Defining the principle of who and what really counts. Academy of Management Review 22(4): 853-886.

Nag R, Corley KG and Gioia, DA (2007) The intersection of organizational identity, knowledge, and practice: Attempting strategic change via knowledge grafting. Academy of Management Journal, 50(4): 821-847.

Nikolova N and Devinney TM (2009) Influence and power dynamics in client-consultant teams. Journal of Strategy and Management 2(1): 31-55.

Nikolova N, Möllering G and Reihlen M (2014) Trusting as a 'Leap of Faith': Trust-building practices in client-consultant relationships. Scandinavian Journal of Management, [online]. 
Petkova A (2012) From the Ground Up: Building Young Firms' Reputation. In: Barnett ML and Pollock TG (eds) The Oxford Handbook of Corporate Reputation. Oxford: Oxford University Press, 383-401.

Pfarrer MD, Pollock TG and Rindova VP (2010) A tale of two assets: The effects of firm reputation and celebrity on earnings surprises and investors' reactions. Academy of Management Journal 53(5): 1131-1152.

Pfeffer J and Salancik GR (2003) The external control of organizations: A resource dependence perspective. Stanford University Press, Stanford, CA. Podolny JM (2005) CEO as change agent. Organization Science 2(6): 71-78. Pollock TG, Lee PM, Jin K and Lashley K (2015) (Un)Tangled: Exploring the Asymmetric Coevolution of New Venture Capital Firms' Reputation and Status. Administrative Science Quarterly, 1-36 [early view].

Pollock TG and Rindova VP (2003) Media legitimation effects in the market for initial public offerings. Academy of Management Journal, 46(5): 631-642.

Pratt MG and Foreman PO (2000) Classifying managerial responses to multiple organizational identities. Academy of Management Review 25(1): 8-42.

Pratt MG, Rockmann KW and Kaufmann JB (2006) Constructing professional identity: The role of work and identity learning cycles in the customization of identity among medical residents. Academy of Management Journal 49(2): 235-262.

Randel AE, Jaussi KS and Standifird SS (2009) Organizational Responses to Negative Evaluation by External Stakeholders. The Role of Organizational Identity Characteristics in Organizational Response Formation. Business \& Society 48(4): 438-466.

Ravasi D and Schultz M (2006) Responding to organizational identity threats: Exploring the role of organizational culture. Academy of Management Journal 49(3): 433-458. 
Rhee M and Valdez ME (2009) Contextual factors surrounding reputation damage with potential implications for reputation repair. Academy of Management Review 34(1): 46-168. Rhee M and Kim T (2012) After the collapse: A behavioral theory of reputation repair. In: Barnett ML and Pollock TG (eds) The Oxford Handbook of Corporate Reputation. Oxford: Oxford University Press, 446-465.

Rindova VP and Fombrun CJ (1999) Constructing competitive advantage: The role of firmconstituent interactions. Strategic Management Journal 20(8): 691-710

Rindova VP and Martins LL (2012) Show me the money: A multidimensional perspective on reputation as an intangible asset. In: Barnett ML and Pollock TG (eds) The Oxford Handbook of Corporate Reputation. Oxford: Oxford University Press, 16-33.

Rindova VP, Williamson IO and Petkova AP (2010) Reputation as an Intangible Asset: Reflections on Theory and Methods in Two Empirical Studies of Business School Reputations. Journal of Management 36(3): 610-619.

Rindova VP, Petkova AP and Kotha S (2007) Standing out: how new firms in emerging markets build reputation. Strategic Organization 5(1): 31-70.

Rindova V, Williamson, IO, Petkova, AP and Sever JM (2005) Being good or being known: an empirical examination of the dimensions, antecedents, and consequences of organizational reputation. Academy of Management Journal 48(6): 1033-1049.

Sherer PD and Lee K (2002) Institutional Change in Large Law Firms: A Resource Dependency and Institutional Perspective. Academy of Management Journal 45(1): 102-119. Starbuck WH (1992) Learning by knowledge-intensive firms. Journal of Management Studies 29(6): 713-740.

Sturdy A (2011) Consultancy's consequences? A critical assessment of management consultancy's impact on management. British Journal of Management 22(3): 517-530. 
Sturdy A, Wylie N and Wright C (2013) Management Consultancy and Organizational Uncertainty. International Studies of Management and Organization 43(3): 58-73.

Suchman MC (1995) Managing legitimacy: Strategic and institutional approaches. Academy of Management Review, 20(3): 571-610.

Sueddeutsche Zeitung (2004) Full reference removed to anonymise company.

Sveningsson S and Alvesson M (2003) Managing managerial identities: Organizational fragmentation, discourse and identity struggle. Human Relations 56(10): 1163-1193.

Von Nordenflycht A (2010) What is a Professional Service Firm? Toward a Theory and Taxonomy of Knowledge-Intensive Firms. Academy of Management Review 35(1): 155-174. Walker K (2010) A Systematic Review of the Corporate Reputation Literature: Definition, Measurement, and Theory. Corporate Reputation Review, 12(4): 357-387.

Watson TJ (2008) Managing Identity: Identity Work, Personal Predicaments and Structural Circumstances. Organization 15(1): 121-143.

Weick KE (1979) The social psychology of organizing. $2^{\text {nd }}$ edition. Addison-Wesley Pub. Co., Reading, MA.

Whittle A (2005) Preaching and practising 'flexibility': Implications for theories of subjectivity at work. Human Relations 58(10): 1301-1322.

Whittle A (2006) The paradoxical repertoires of management consultancy. Journal of Organizational Change Management 19(4): 424-436.

Yin RK (2009) Case Study Research. Design and Methods. $4^{\text {th }}$ edition. Sage Inc., Thousand Oaks, California. 
Table 1: Illustrative quotations on identity claim, reputation conflict and remediation

\begin{tabular}{|c|c|}
\hline Themes & Illustrative quotations \\
\hline $\begin{array}{l}\text { Identity } \\
\text { claims } \\
\text { Entrepreneur- } \\
\text { ial identity }\end{array}$ & $\begin{array}{l}\text { I think it's very entrepreneurial. It's a small office, and so, you can sometimes get more } \\
\text { responsibility. If you prove yourself, even on your first project, the senior management won't } \\
\text { wait for next for you to get promoted to next level - you'll start working at that level without } \\
\text { your title, but you'll get the same kind of responsibility of next level, if you prove yourself, so } \\
\text { it's very entrepreneurial (Junior Consultant). } \\
\text { I believe that this is our entrepreneurial spirit. So entrepreneurship is one of our values, and I } \\
\text { think that we succeeded in communicating this externally. We are very willing to take risks. } \\
\text { We ask our employees to take responsibility right from the start, right from day one (Manager). } \\
\text { [Our] strongest reputation now, if we are speaking from today, not } 15 \text { or } 20 \text { years ago, it's the } \\
\text { European management style (Partner) }\end{array}$ \\
\hline $\begin{array}{l}\text { European } \\
\text { identity }\end{array}$ & $\begin{array}{l}\text { First off, in the consulting market, it's a [...] European based consulting company, compared to } \\
\text { all our main competitors. This is really what differentiates [Augur Insights] (Manager) }\end{array}$ \\
\hline $\begin{array}{l}\text { Strategy with } \\
\text { a difference/ } \\
\text { Pragmatism }\end{array}$ & $\begin{array}{l}\text { I think we are very pragmatic, so we don't only develop nice charts and leave our clients alone } \\
\text { with this, but we also support them in the implementation phase. We are really people who roll } \\
\text { up the sleeves, getting things done. Probably a little bit more down-to-earth than the others. } \\
\text { (Manager) }\end{array}$ \\
\hline & $\begin{array}{l}\text { Although we say we are pragmatic } 80 / 20 \text {, we want to make sure we deliver a great product, so } \\
\text { the way we work is probably more intensive than some other people. We stay very long until } \\
\text { we think we have the best what we can do. So we drive for this excellence internally. There's } \\
\text { this culture (Partner). }\end{array}$ \\
\hline $\begin{array}{l}\text { Reputation } \\
\text { conflict } \\
\text { Meaningless } \\
\text { or } \\
\text { inconsistent }\end{array}$ & $\begin{array}{l}\text { Ever since consulting firms came under fire in the early 1990s for selling blanket solutions } \\
\text { without attention to company-specific details, the major players have been eager to push a } \\
\text { different image (Wall Street Journal, 1999). } \\
\text { I would now say that the reputation [is], from talking to client and non-clients, would be as } \\
\text { what I call strategic operations rather than strategy. [...] So a lot more of our reputation would } \\
\text { be for implementation rather than for thinking great thoughts, which is generally what strategy } \\
\text { means. (Partner) } \\
\text { But what does this mean, to be European? I mean, yes, we are... our Headquarters are in } \\
\text { [Europe], but this doesn't mean anything. (Partner) }\end{array}$ \\
\hline $\begin{array}{l}\text { Remediation } \\
\text { Shifting levels }\end{array}$ & $\begin{array}{l}\text { The firm is built on the individual partners. You buy the partner and the team then you might } \\
\text { be buying the firm. (Client). } \\
\text { If I buy consulting I choose on the basis of the team in front of me at the pitch not the brand of } \\
\text { the firm. What matters is the team, the leader and their experience. (Client). } \\
\text { I don't buy the firm, I buy the people. I buy the lead partner and the relationship with him or } \\
\text { her. If the people change I change my view of my relationship with the firm. (Client, Financial } \\
\text { Services). }\end{array}$ \\
\hline $\begin{array}{l}\text { Trust building } \\
\text { from thought } \\
\text { leadership } \\
\text { claims }\end{array}$ & $\begin{array}{l}\text { We gained a reputation for thought leadership, which wasn't there before, [was always me too } \\
\text { guys]. Thanks to a lot of work, of Marketing especially in publications like [anonymised] } \\
\text { content really influenced our image. Press coverage has improved strongly. (Principal) } \\
\text { Some new marketing tools like our [anonymised] magazine which is sent out to the CEOs of } \\
\text { the most important companies here in Germany and also, on the international level, in some } \\
\text { other languages - in English, Russian, Chinese, and so on. This is part of the improvement of } \\
\text { our reputation, especially regarding our [thought] leadership. (Partner) }\end{array}$ \\
\hline $\begin{array}{l}\text { Emphasizing } \\
\text { value }\end{array}$ & $\begin{array}{l}\text { So from you know, working there as an employee, I know they have a reputation for basically } \\
\text { long hours and sort of an over-attention to detail (ex-consultant, now Client) } \\
\text { If somebody has worked with us a couple of times, then they would recognise they can get } \\
\text { more (Partner). }\end{array}$ \\
\hline
\end{tabular}


Figure 1: Remediating reputation conflict

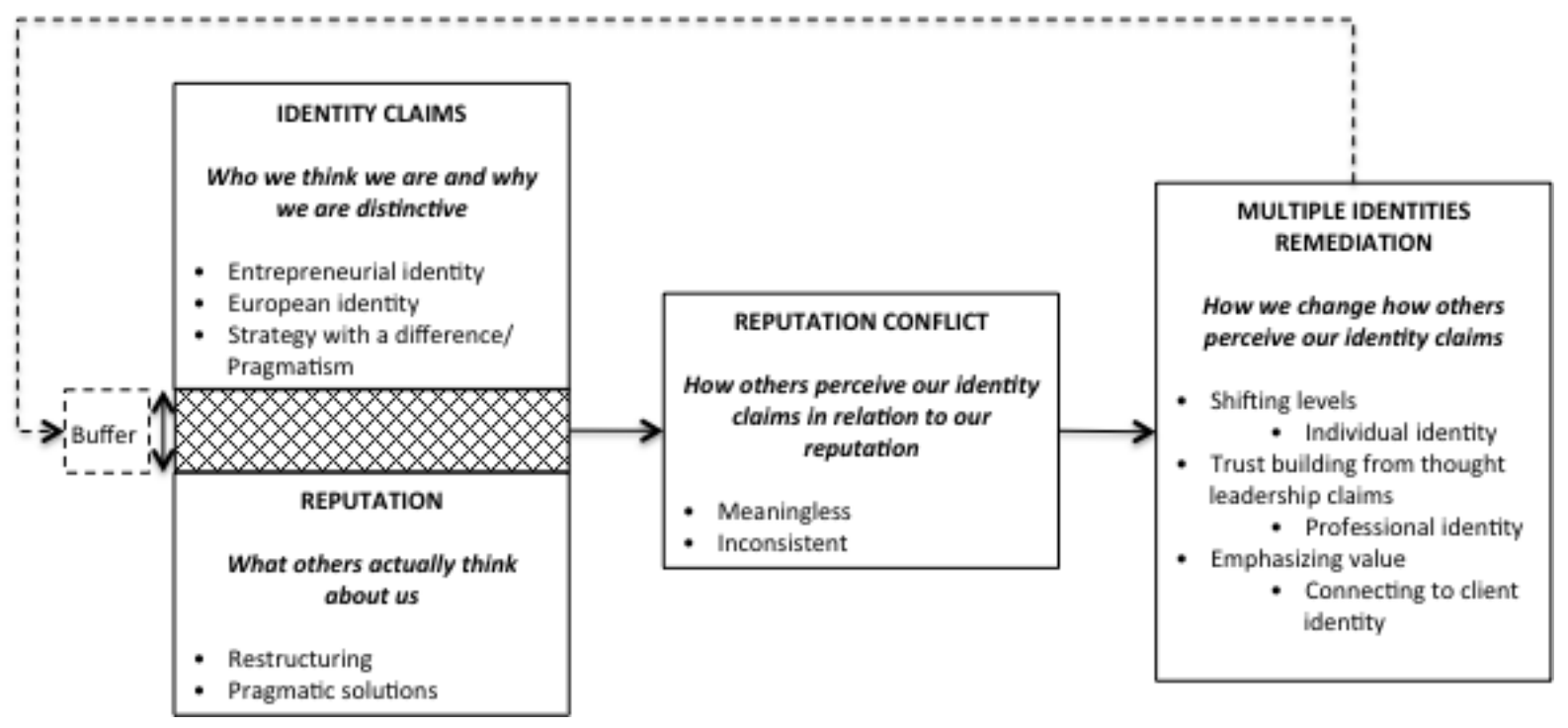




\section{Corresponding author:}

William S. Harvey

Business School

University of Exeter

\section{EXETER}

William S. Harvey is Director of the Public Policy Research Cluster, Director of Research and Senior Lecturer in Organisation Studies at the University of Exeter Business School, and an Honorary Senior Lecturer at the University of Sydney. William's research focuses on the mobility, economic impact and social networks of talented workers; reputation and leadership within professional service firms; practical challenges with fieldwork and interviewing business and political elites. He has published articles in a wide-range of scholarly journals in business and management, sociology, geography, migration and industrial relations. [Email: william.harvey@exeter.ac.uk].

\section{Other authors:}

Timothy Morris

Saïd Business School

University of Oxford

OXFORD

OX1 1HP

UK

Timothy Morris is Professor of Management Studies at the University of Oxford. His research interests are focused on the strategic management, innovation processes, reputation and institutionalization of professional service firms and the interaction between professions and the organizations in which they work. He has published in a number of scholarly journals including the Academy of Management Journal, Journal of Management Studies, Human Relations, Journal of Organization Behavior and Organization Studies. [Email: tim.morris@sbs.ox.ac.uk].

Milena Müller Santos

Saïd Business School

University of Oxford

OXFORD

OX1 1HP

UK

Milena Müller Santos is a Research Assistant at the Said Business School, University of Oxford where she also holds a DPhil in Organisational Studies [Email:

milena.muellersantos@sbs.ox.ac.uk]. 